\title{
What are you looking at?
}

\section{Editors:}

Jaime Almansa Sánchez \& Elena Papagiannopoulou

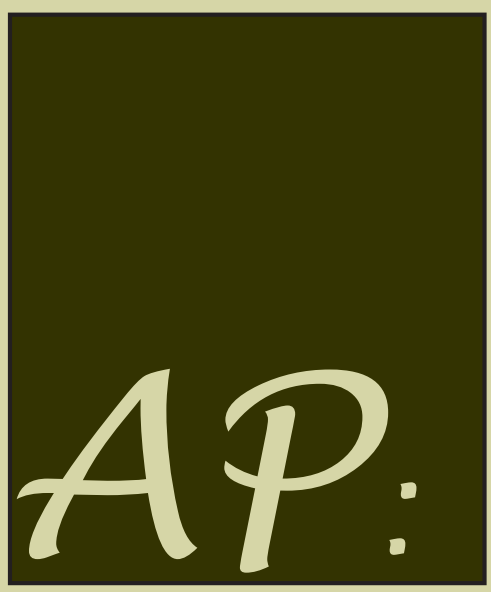

www.arqueologiapublica.es

Ontine Journat in Public Archaeotogy 


\section{What are you looking at?}

\section{Editors:}

Jaime Almansa Sánchez and Elena Papagiannopoulou

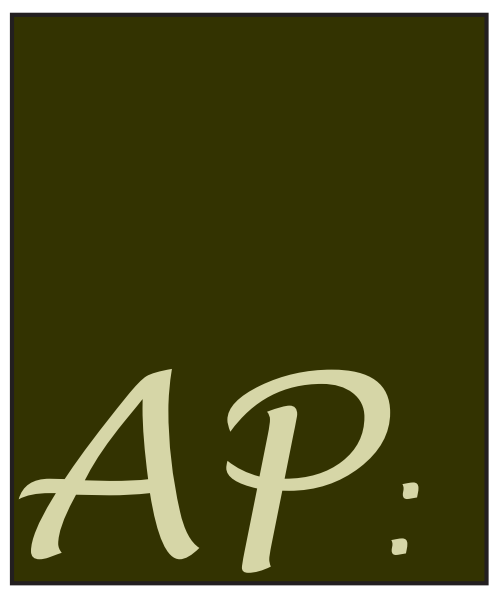

www.arqueologiapublica.es

Ontine Journat in Public Archaeology

AP: Online Journal in Public Archaeology is edited by JAS Arqueología S.L.U. 


\section{INDEX}

Editorial

Jaime Almansa Sánchez and Elena Papagiannopoulou

Forum:

The looting of archaeological heritage (Part II)

Sabita Nadesan, Ivana Carina Jofré Luna \& Sam Hardy

Forum:

Archaeology as a tool for peacemaking

Adi Keinan-Schoonbaert, Ghattas J. Sayej \& Laia Colomer Solsona

Roșia Montană: When heritage meets social activism, politics and community identity

Alexandra Ion

Using Facebook to build a community in the Conjunto Arqueológico de Carmona (Seville, Spain)

Ignacio Rodríguez Temiño \& Daniel González Acuña

In Search of Atlantis:

Underwater Tourism between Myth and Reality

Marxiano Melotti

The past is a horny country

Porn movies and the image of archaeology

Jaime Almansa Sánchez

Points of You

The forum that could not wait for a year to happen \#OccupyArchaeology

Yannis Hamilakis, with a response by Francesco Iaconno

Review

Cultures of Commodity Branding

David Andrés Castillo 
Cultural Heritage in the Crosshairs

Ignacio Rodríguez Temiño

\section{Review}

US Cultural Diplomacy and Archaeology

Ignacio Rodríguez Temiño

Review

Archaeological intervention on historical necropolises

Rafael Greenberg

Review

Arqueológicas. Hacia una Arqueología Aplicada

Xurxo Ayán Vila

\section{Review}

Breaking New Ground

Doug Rocks-MacQueen

\section{Review}

Cultural Heritage and the Challenge of Sustainability

Jaime Almansa Sánchez

\section{Review}

Archaeology in Society and Daily Live

Dawid Kobiałka 


\title{
The Past is a Horny Country:
}

\section{Porn Movies and the Image of Archaeology}

\author{
Jaime ALMANSA SÁNCHEZ \\ JAS Arqueología S.L.U.
}

\begin{abstract}
Do you watch porn? Most people lie when answering this question. The pornographic industry would not be as big as it is if nobody consumed it. As with other cultural expressions, archaeology and the past are also represented in porn movies, affecting the public image of our discipline as it does advertising, literature, or cinema. This paper explores and analyses the multiple references to the past and our profession found within the context of pornographic movies and other erotic products, highlighting the potential of pornography as another tool for informal education.
\end{abstract}

\section{Keywords}

Porn, Eroticism, Archaeology, Image, Perception, Education

\section{Parental advisory: Explicit content}

I believe everyone recalls the oft-quoted opening line from L.P. Hartley's The Go Between (1953): "The past is a foreign country: they do things differently there." Archaeologists will also recall the homonymous book by David Lowenthal (1985). For me, Lowenthal's book has been essential in shaping my idea of public archaeology, and more specifically in understanding the implications of the past in the present. This paper is a tribute to that book, which Cambridge University Press is going to "revisit" soon (Lowenthal 
2015). And without intending to sound disrespectful, I believe pornography is one of the primary sources for the study of public perceptions of archaeology. After all, pornography and sex are essential expressions of humankind that we need to make less taboo (Attwood and Smith 2014).

\section{Laughing with the past}

Those of us who grew up watching The Flintstones or Captain Caveman are very familiar with two of the main stereotypes about the prehistoric past; there were rude, dirty, and underdeveloped human beings adorned with bones and fur... and there were dinosaurs. Fun as this genre was, cinema became deluged with an interminable list of movies from which we learnt that the best way for a prehistoric man to have sex was to club a cavewoman on the head, grab her by the hair, and drag her back into the cave. Simple as that. I cannot recall the number of times I have seen this image, or even in the reverse, when a cavewoman grabs the caveman by his penis.

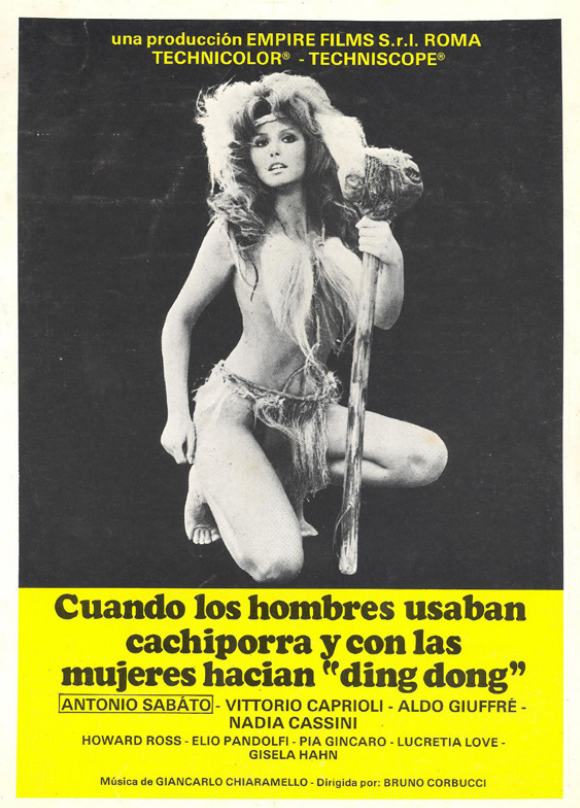

Fig1. Quando gli uomini armarono la clava e... con le donne fecero dindon (1971) 
Popular humour often takes ideas, sometimes obscene, from the past and archaeology. One of the first archaeologically-themed dirty jokes that comes to mind is, of course, the term Homo erectus itself, which was recently used in a monologue for the FameLab Spain science and engineering competition, as well as in the title of a pornographic movie. Again, simple as that. Academia has also faced this issue, although not in any serious manner. The huge amount of pornographic materials we inherited from the past contributed to the writing of two books by Paul Bahn and Bill Tidy; Ancient Obscenities (1999a) and Disgraceful Archaeology (1999b), which I still do not know if are the same. The popularity of these books indicates that sex is so taboo in certain contexts that they become part of the game, as it were. The gender roles and stereotypes inherent in this sort of humour speak not only about archaeology or the past, but also about our society today. Recent feminist critiques (i.e. Soler 2012; Querol 2014), for instance, quite rightly point to the fact that images of women and their traditional roles in representations of the past impact upon gender equality today. It is indeed worrying when we laugh at fictional cavemen using a club to dominate women and have sex. But what also requires examination is the easy synonymy with the prehistoric past and sexual roles; even the television show Family Guy utilised this concept in an episode ("Quest for Fur") which showed one of its main characters, Lois Griffin, on a porn movie set that was meant to look like the prehistoric past.

\section{Advertising bodies}

In my recent monologue for Famelab Spain (http://youtu.be/_ IsVjJ0zK08), I used the example of Angelina Jolie's body in the Tomb Raider movie as a determinant factor for many in being interested in archaeology. Because as cool as Harrison Ford is, he is not cool enough for heterosexual young men. Since I first used it 
in a presentation at the 2008 EAA Meeting, it has worked as a joke; people laugh at it. But the reason why I used this joke is because Lara Croft was designed to attract young gamers in the first place. As we all know, advertisements commonly use this role of woman-asobject to attract heterosexual male consumers through eroticism, which has long been denounced by feminist groups and intellectuals (Barthel 1988; and a good overview at Blloshmi 2013). But it is also problematic that when targeting women or gay consumers, advertisements also employ a man-as-object perspective (Craig 1992). All in all, the number of eroticised images in traditional product advertising-whether explicit or not-are endless, from the gorgeous woman trying to convince you to buy a perfume to smell (and look) like her, to the beautiful man who becomes irresistible to women wearing the same kind of perfume, or the muscular man selling gym subscriptions.
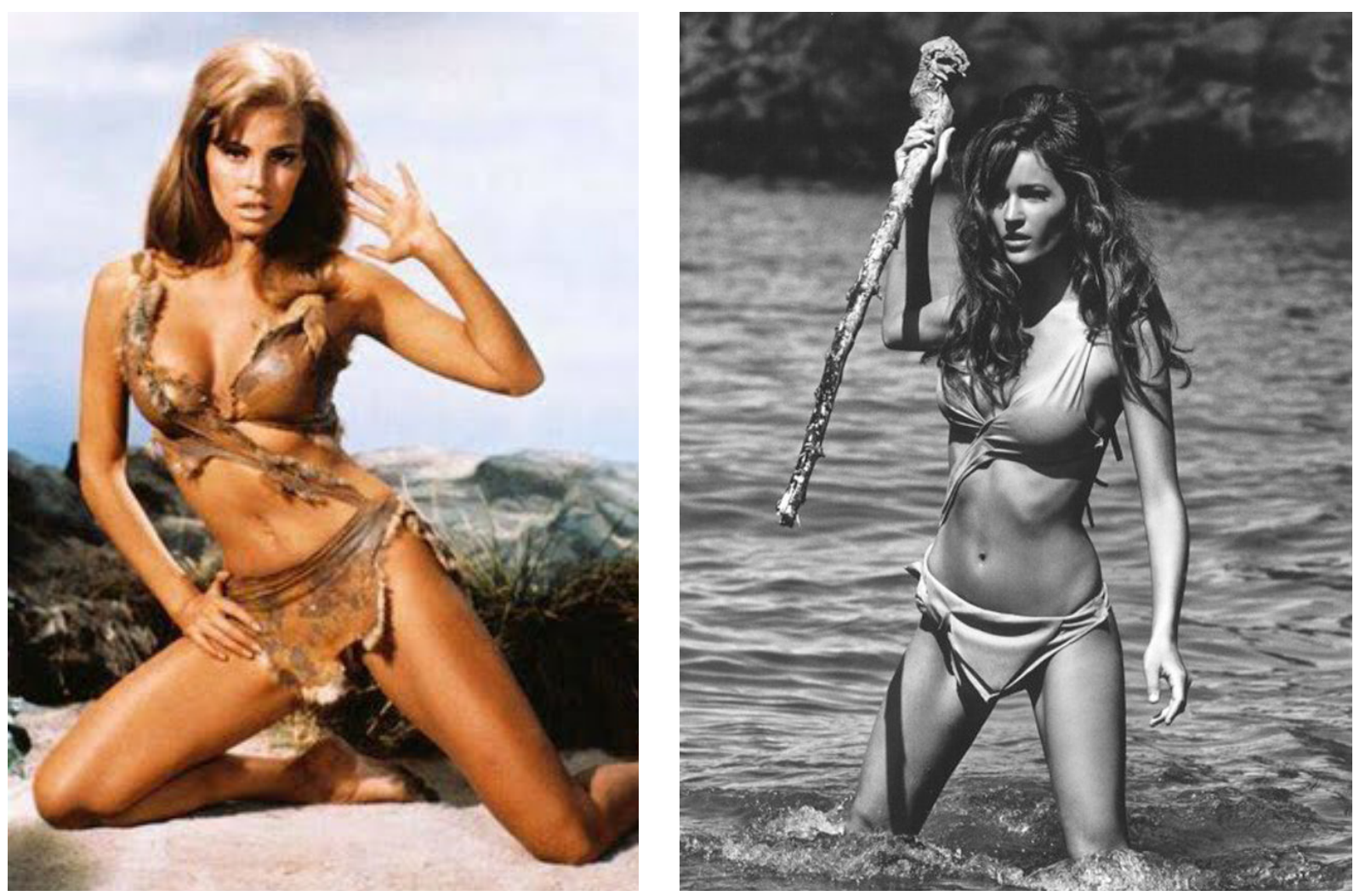

Fig. 2: Rachel Welch \& Malena Costa (@GQ) 

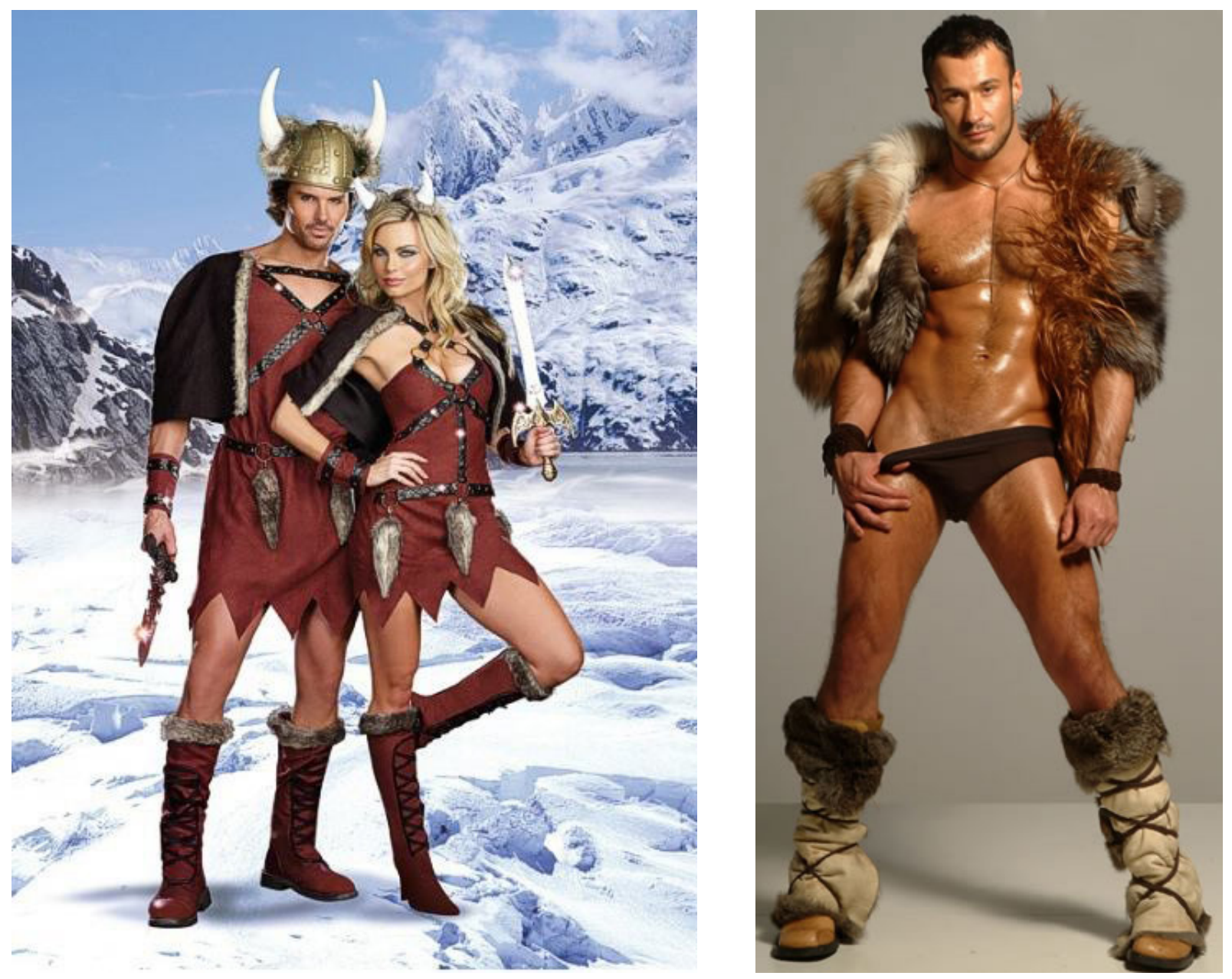

Fig. 3: Some sexy costumes (from the internet)

Movies are no different, with casting frequently being a type of advertising in itself. The iconic image of Raquel Welch in One Million Years B.C. endures, as does that of 1968 Playboy Playmate of the Year Victoria Vetri in When Dinosaurs Ruled the Earth. In 2013, a special volume on iconic bikini poses in movies in the Spanish edition of the fashion magazine $G Q$ had the famous model Malena Costa wearing-what else?-the fur bikini of Raquel Welch and holding a club. The only saving grace of that photo shoot was that they left the dinosaurs out (Fig. 2). Beauty in the movies is a must for most blockbuster products, and this applies to both women and men. Can you imagine Indiana Jones starring John Goodman or Woody Allen? The latter is not even the protagonist of his own The Purple Rose of Cairo. 
Television shows continue this tradition, with the new generation of cable shows capitalising on the lack of censorship to make sex part of the plot, such as in Rome (HBO) or Spartacus (Starz). The British comedy Plebs (ITV2), which is set during Roman times, at least presents an erotic plot with no explicit sex. In Spartacus, sex is in truth not essential for plot progression, but is merely a ploy to attract more viewers. Rome and Plebs show the reality of sex from a 'historical' perspective. The former highlights the cruelty of humanity by weaving rapes, prostitution, complots, and affairs in the plot, which are essential to understand the characters' interactions and personalities. Plebs, meanwhile, is about two young citizens who recently landed in ancient Rome and their quest for sex. Although I have in the past only referenced the present article as a joke, it does bear repeating in light of the above: if sex did not sell, there would not be so much of it.
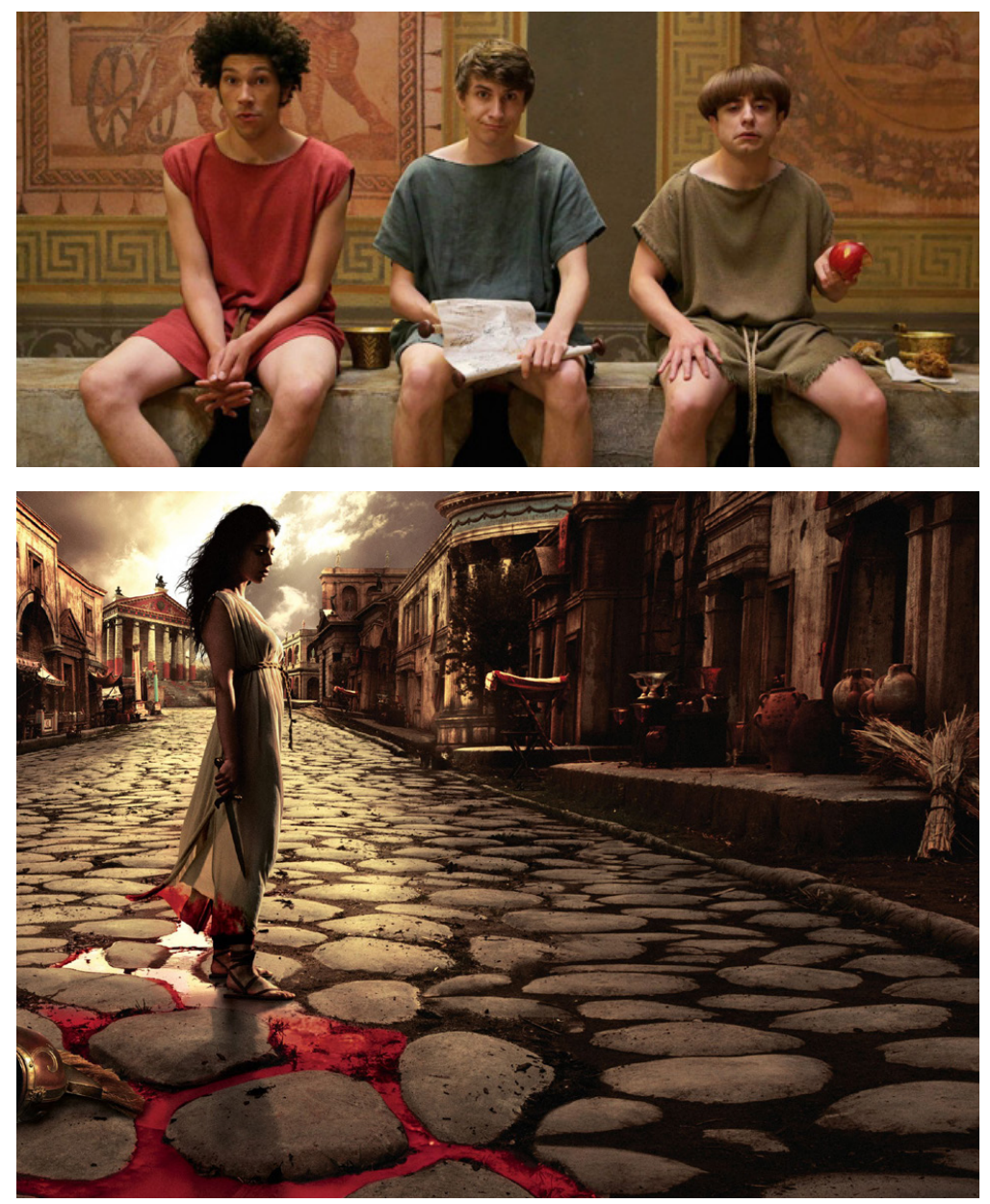

Fig. 4: Plebs (ITV) and Rome (HBO) 
We don't do dinosaurs!

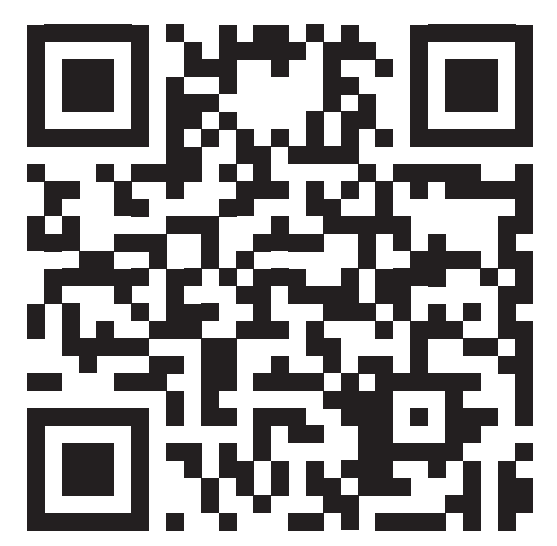

http://youtu.be/Ln5W1EbYAW0

*Thank you Adobe for making it impossible to embed online videos with the latest version of your software.

Have you seen this video? ArchaeoSoup Productions bring us some of the smartest and funniest reflections on archaeology. Undoubtedly, dinosaurs are one of the topical themes of our conversations with the non-archaeologists we occasionally meet.

- So, what do you do for a living?

- I'm an archaeologist.

- Oh! So cool! Have you found any dinosaurs?

I believe we have all had this conversation at some point in our lives. Movies and TV series like the ones mentioned above show humans interacting with dinosaurs, projecting the image-and sending out the message-that human prehistory was full of them. There are even some pseudo-archaeological phenomena, such as the Ica stones in Peru, which also try to pair us with dinosaurs in some lost prehistoric era. 
While I was researching this article I came across some disturbing images, videos, and even books that I could hardly imagine existed. The 'softest' of these was gay dinosaur cartoon porn, because it involved no human beings. But humans are involved in the new literary genre made popular in the mass media: 'dinosaur porn' (Beck 2013). Obviously influenced by the Japanese 'monster porn' phenomenon, some folk in USA decided to write erotic stories in which dinosaurs are somehow copulating with women.

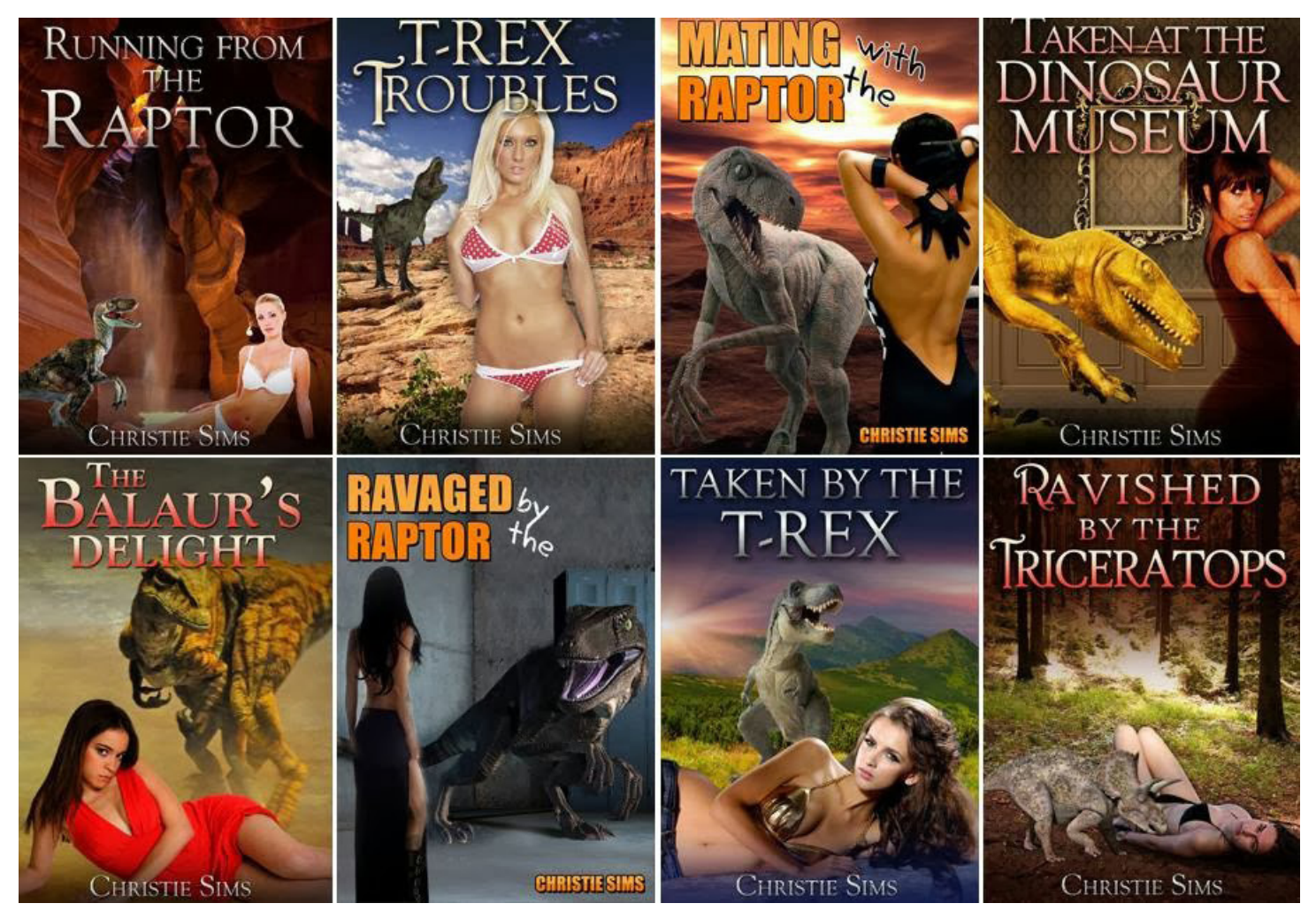

Fig. 5: Curious? Have a look at some of the covers!

Following the success of the dinosaur porn pioneers on Amazon, other authors decided to cash in, even producing Spanish versions of these stories. Sex is obviously on display in these novels, but here, the sex happens between male dinosaurs and female humans in a way I hardly understand and find distasteful. Not even The Flintstones porn parodies I have found (besides the comics) have dinosaurs so central to the plot. Of course, these stories are not situated in a specific historical moment or period, and there is lack of context. But context never really matters in porn. 
That said, I have to admit that the now infamous video of three Pterodactyls having sexual intercourse with a woman has been really successful in every social gathering I have attended lately. But it also makes me wonder if we are actually that twisted. I will not embed the video in this article, but you can Google it if interested. I will just add that this video has become an Internet meme, and even has its own entry in Urban Dictionary.

\section{Can we learn anything about archaeology by watching porn?}

I quoted Paul Bahn at the beginning of this article and I will quote him again now. His latest book with Bill Tidy, Dirty Diggers (2013), has enough sexual anecdotes to plot some porn movies. It appears that we have a promiscuous profession, so why not our own porn genre?

\section{The past as plot: All excuses are good for sex}

It is said that there is no need for plot in porn. Normally, scenes occur for no apparent reason. However, some genres appear to be more successful in response to traditional sexual fantasies (Barker 2014). As a matter of fact, some porn movies offer a quite elaborate plot; sex still happens for no reason but there is, at least, a background story.

I have already commented on The Flintstones and other television shows or movies in which dinosaurs and humans are supposed to coexist, which I of course consider to be pure fiction (if any of the other movies could be tagged as non-fiction). So the classic Homo erectus, together with other movies and movie scenes in which actors play Palaeolithic humans. Unfortunately, I cannot offer any statistics on the topic, as the nearly fifty videos of movies and scenes I have collected is just a small sample of the total that 
may exist. But judging from these alone, cavemen and cavewomen feature quite prominently. The actors' outfits are exactly the same as in other productions, such as documentaries, and respond to the image most people have of cavemen and cavewomen. It might be an easy period to perform-but because there are no dinosaurs around, and if you overlook the silicone, these movies are at least of more historical value than other Hollywood productions like 10,000 B.C., where the plot has no historical sense at all.

Egypt is another popular setting. Films like Cleopatra-the inspiration behind this article-or The Pyramid are now porn classics too. In these movies, plots go wild with nonsensical stories of resurrection and sex, but the markers of this genre are clear: the mummies, pharaohs, and even museums. The props are very similar to those shown in any other movie or documentary, although there are some low budget productions that just paint some kind of hieroglyphs in the paper wall, and adorn their actors with shiny paper headdresses and a white bed sheets. The Greekthemed porn movies feature mythological stories, where Hercules, Ulysses, and other gods and goddesses copulate in stories with no plot. But these movies manage to employ decent props, especially in the remarkable porn parody of 300 .

For the Iron Age, I only found an XXX parody of Asterix and Obelix. But the Roman age is especially popular, second only to the Palaeolithic and Egypt, with several productions of great quality. Rome and Gladiator are two three-part productions with an excellent setting and a solid plot. Caligula has an XXX version too, with a very similar look to the original show. In all these cases, one can actually see some interesting details about daily life in Rome that are hardly found in some blockbuster productions from Hollywood.

The tendency is similar in other pornos with historical settingsthey all present some stereotypes and some fantasy adorned with 
cheaper replications of Hollywood props. However, after watching all of these movies, I began to wonder: can we actually learn something from these porn movies? I remember watching $\mathrm{La}$ guerre du feu in school; but I feel that some tiny changes in the plot of Homo erectus would make it just as educational as the former (excepting the porn, of course). The same is true of Rome.

\section{The professional in the plot: How do we look?}

I began a recent article on archaeology and daily life by noting "I wish I was Harrison Ford" (Almansa 2013a). It would be too easy a joke to say I want to be like one of the actors in a porn movie, so I will stay with Harrison Ford. Archaeologists are highly appreciated characters in popular culture, and the archaeo-appeal (Holtorf 2005: chapter 9) of the profession is a reality we all have experienced. It is, in all probability, this same archaeo-appeal that causes the past to feature so prominently in porn movies, and also why the character of the archaeologist appears in so many of them.

As expected, most of these movies feature derivations or parodies of Indiana Jones, as the character has become a pop culture icon. This means that the figure of the archaeologist that appears in pornos and other mass media forms is based on fiction-adventurers with hats, brown explorer clothing, and sometimes whips-rather than the more mundane reality of actual professional archaeologists.

Remarkably, the closest depiction of actual archaeological activity in the movies I have researched is a visit to Egypt and a museum. Except for Road to Atlantis (2004), which shows two archaeologists engaged in an 'excavation' - that is, digging with their hands until they get a small artefact-there is, oddly enough, no sign of archaeology around the archaeologists. The two parodies of Indiana Jones I found, Carolina Jones (2008) and Indiana Mack (2000 and 2001), are more adventure-themed pornos than anything else. 
Guy 1: Hang on! This is a discovery, let's do a little research on our own first... Hey! Someone is coming over.

Antiques: Good afternoon gentleman. Working hard I see.

Guy 1: Are you with the dig?

Antiques: Not exactly... My card [...] I specialize in ancient art. I pay very good.

Guy 1: But this is a university sponsored dig.

Guy 2: Yes, everything we excavate belongs to the Greek government.

Antiques: I sometimes find cash can be a benefit for young men like yourselves.

Guy 1: It is guys like this, they rob the tombs and sell the stuff in the black market. You think our discovery is safe?

Road to Atlantis (2010)

"This belongs to the museum

My father is Indy Jones

Hey you got a pussy, don't you? Use it or lose it"

The thoughts of Carolina Jones before sleeping...

Carolina Jones (2008)

Smuggling Sexpedition (2012) deserves special mention, however. The movie is about a group of looters who are being pursued by the police. There is a clear establishment of good and evil in the plot, which ends in a spectacular pursuit featuring a helicopter. Although there are no archaeologists in the story, the message was still clear: looting is bad.

Despite these erroneous depictions, however, it must be noted that we ourselves hardly shun the 'adventurer' in our professional lives. In truth, when we analyse the image of archaeology and archaeologists (see any of the already quoted works on the topic), we can focus on different issues, depending on our own research interests. For instance, if we want to evaluate the knowledge of a period, we will try to see how this period has been understood 
and represented. From the time I started writing papers (Almansa 2006), I have always been interested in the image of the profession and the professional, and this article is admittedly biased by this perspective.

\section{Learning about archaeology by watching porn}

So we need to ask ourselves whether anyone can learn anything about archaeology when watching porn. The porn movies with archaeological themes described above are too varied in their plots and production values to discern any one message, especially because they are being analysed by a single researcher with a singular point of view. It is for this reason that I propose a controlled study of these movies by non-archaeologists, who might be better able to offer a non-biased analysis of the contents and the learning possibilities of porn for archaeology.

The current figures for porn consumption, straight and gay, masculine and feminine oriented ones are astonishing (just see PornHub Insights Stats for one single online site: http://www. pornhub.com/insights/category/stats/), although there is still a lack of research (Voss 2012). This means that the opportunities inherent in using porn as an educational tool-if we can use the word 'education' here-are enormous. We usually talk about audiences, the public, communities, etc., and forget the fact that most of our work is geared towards a section of the public that already values archaeology and engages with it. As well as other audiovisual cultural products that have been understood as informal education, pornography has the capacity to reach an audience that is significantly broader than any notion of 'audience' that we might envision. And so, depending on the goals we are trying to achieve, using porn can actually help change some stereotypes and preconceived ideas about the past, about archaeology, and about 
archaeologists. However, in order to do that, we need to take part in the process.

\section{Epilogue}

Shall we get involved in the porn industry? When we do not even have any real impact in the production of other, more conventional cultural products that reference archaeology, trying to establish a base here might sound idealistic. However, where the developers of cultural products once occupied a different world, they are now part of ours-so our involvement may just be a matter of need and time. We tend to think about innovation in terms of technology, but work niches can be innovative too. If there is an opportunity, we should take it.

While I write these lines, a colleague has just entered a discredited TV show to look for a couple in Spain. This show is more popular than any in its timeslot, and her explanation of what archaeology is in the first two minutes of the show will probably be more successful in terms of public education than any of our efforts this year. Also, an April Fool's Day prank about archaeology was nominated as best radio comedy in Germany this year. Archaeologists in collaboration with a German radio station prepared it, and thousands of people listened in (Scherzler 2014). We, from JAS, are currently supporting a radio serial with a background context of archaeology (García 2014), and publishing a novel about preventive archaeology (Guerra 2012). Why not going further?

The lack of real specialists consulting for mass media productions and cinema is a fact that we should try to address, and porn can be seen as another avenue. The fact remains that the current image of archaeology, archaeologists, and the past that is depicted in porn movies does not differ much from that depicted in other conventional media. So whatever space there is for improvement 
should be capitalised upon. In the same way advertising overuses the term 'heritage' (Almansa 2013b), we should also try to have our say. Because overlooking porn for any reason entails overlooking millions of porn consumers as a potential audience that could be positively influenced to value and understand our work.

Writing this text I have imagined several plots for successful porn movies with a strong archaeological message. The past is a horny country, and our lives are quite evocative too. If we have any opportunity in any context in which archaeology can be made to look good to members of the public-in porn or otherwise-then it would be remiss not to take it.

\section{References}

Almansa, J. 2006. La imagen popular de la arqueología en Madrid. ArqueoWeb 8(1) http://pendientedemigracion.ucm.es/info/ arqueoweb/pdf/8-1/almansa.pdf

Almansa, J. 2013a. A problem of value? Public perceptions of the past and daily-life archaeology in Spain. In Archaeology in Society and Daily Life. Challenges and cooperation in the $21^{\text {st }}$ Century. Pinkarmaa Provintial Museum, 26-33.

Almansa, J. 2013b. Arqueología Pública en España. JAS Arqueología Editorial.

Attwood, F. and Smith, F. 2014. Porn Studies: an introduction. Porn Studies 1(1-2), 1-6.

Bahn, P. and Tidy, B. 1999a. Ancient Obscenities. Tempus Publishing. Bahn, P. and Tidy, B. 1999b. Disgraceful Archaeologies. Tempus Publishing.

Bahn, P. and Tidy, B. 2013. Dirty Diggers. Tales from the archaeological trenches. Left Coast Press.

Barker, M. 2014. The 'problem' of sexual fantasies. Porn Studies $1(1-2), 143-160$. 
Barthel, D.L. 1988. Putting on appearances: Gender and advertising. Temple University Press.

Beck, L. 2013. Dinosaur Erotica exists and it's just as amazing as you imagine. Jezebel 01/10/13 http://jezebel.com/dinosaurerotica-exists-and-its-just-as-amazing-as-you-1438081697

Blloshmi, A. 2013. Advertising in post-feminism: The return of sexism in visual culture? Journal of Promotional Communications 1(1), 4-28.

Craig, S. (Ed.) 1992. Men, Masculinity and the Media. Sage.

García, J.I. 2014. Amor Estratigráfico. Capítulo I. JAS Arqueología Editorial. http://amorestratigrafico.blogspot.com./

Guerra García, P. 2012. El Hallazgo. La historia ficticia de un arqueólogo real. JAS Arqueología Editorial.

Holtorf, C. 2005. From Stonehenge to Las Vegas. Archaeology as Popular Culture. AltaMira Press.

Lowenthal, D. 1985. The past is a foreign country. Cambridge University Press.

Lowenthal, D. 2015. The past is a foreign country - revisited. Cambridge University Press.

Querol, M.A. 2014. Museos y Mujeres. La desigualdad en arqueología. ArqueoWeb 15, 270-280 http://pendientedemigracion.ucm. es/info/arqueoweb/pdf/15/Querol15.pdf

Scherzler, D. 2014. "Urschwäbin" entdeckt? SRW2. http://www. swr.de/swr2/wissen/fenster-in-die-steinzeit/-/id=661224/ $\mathrm{did}=13076578 / \mathrm{nid}=661224 / 9 \mathrm{~b} 8 \mathrm{itj} /$ index.html

Soler Mayor, B. 2012. ¿Eran así las mujeres de la prehistoria? In Prehistoria y Cine. Museu Prehistoric de Valencia, 83-100.

Voss, G. 2012. Treating it as a normal business: researching the pornography industry. Sexualities 15(3/4), 391-410. 
Almansa-Sánchez, J. Audiences... A review of the CASPAR session at TAG-on-Sea 2013 (Bournemouth University) - 11 February

Papagiannopoulou, E. Multivocality and Technology: Review of a lecture at the Irish Institute of Hellenic Studies at Athens (IIHSA) - 14 February

Touloupa, S. A 30-year retrospect of the Greek Ministry of Culture educational programmes: an insider's insight - 25 April

Touloupa, S. When Public Archaeology is conflated with Cultural Tourism - 7 July

Ion, A. Some thoughts on the 20th European Association of Archaeologists Conference in Istanbul - 26 September

You can read them at:

http://arqueologiapublica.blogspot.com/ - Reviews 


\section{HOW TO CONTRIBUTE}

AP: Online Journal in Public Archaeology welcomes original contributions that match the aims of the journal and have not been previously published anywhere else, or are not on the way to be published elsewhere. Being online and free can be understood as a sign of quality degradation, but this is not a barrier. It is just a way to adapt from the very first moment to the new panorama in research, where the Internet is the main vehicle for transmission, and more specifically in our field, where the prices of journals are unaffordable for any researcher that is not linked to a research institution. We try to give the widest publicity to the journal, to make it Public.

Having made this clear, the papers can be sent in different ways:

-Mail:

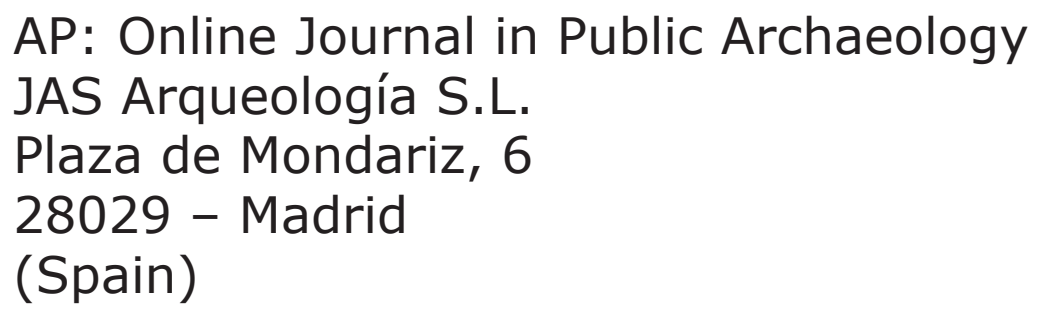

-Email:

jasarqueologia@gmail.com

-Filemail.com:

Filemail.com (www.filemail.com) is a free tool to send large files that exceed the upload limit of a normal email account (Gmail, for example, permits up to $25 \mathrm{Mb}$ ). It is a useful way of sending, for example, large images. In this case, please contact us via email first in case we are not able to get them immediately (the link expires in three days). Of course, any other similar application can be also accepted, like Wetransfer or Dropbox.

\section{STYLE}

Length:

Full articles - We will only accept papers of less than 10.000 words (including notes and references) with a maximum of 10 figures (tables are counted as text). 
Work reports - We will only accept papers of less than 5.000 words (including notes and references) with a maximum of 5 figures (tables are counted as text).

Reviews - We will only accept papers of less than 2.000 words (including notes and references) with 1 figure, that in case of book reviews will be the cover. In other events (conferences, film festivals...), the figure must clearly reflect the event.

Presentation:

To follow the indications of Public Archaeology (www.maney. co.uk/journals/pua), and aiming to standardize the procedures from our side, all material should follow the MHRA Style Guide, which can be freely downloaded from:

http://www.mhra.org.uk/Publications/Books/StyleGuide/index.html

Figures:

The quality of figures should be good enough to be clear in a PDF file. There will not be any weird rule for the submission of the files. Just submit the figures in any readable format (able to be edited in Adobe Photoshop $(\mathbb{B})$. Every camera, software of scanner can make good quality images, so just submit originals. If any figure is subject to copyright it will be essential to attach a written permission from the holder of the rights. To avoid any inconvenience, we encourage the publication of self-owned images. In any case, the author will be responsible for any violation of copyright issues.

Notes and references:

It is preferable to avoid footnotes in the text, just quote or explain in brackets.

For references use Harvard style (Author 2010: 322) followed by a final bibliography. For example: 'according to Author (2010: 123) Public Archaeology can be...' or 'it has been pointed out (Author 2010: 13) that...' etc.

Multiple citations should be in alphabetical order and separated by a semi-colon, (Author et al., 1990; Creator and Author 2003; Producer 1982).

Where an author has several publications from the same year, distinguish them with 'lower-case' letters (Author 2010a, 2010b). Do not use ibid. 
In the final bibliography follow the system below:

Thesis

Castillo Mena, A. 2003. La Gestión del Patrimonio Arqueológico en la Comunidad de Madrid. Unpublished PhD thesis, Universidad Complutense de Madrid.

Journal article

Matsuda, A. 2004. The concept of "the Public" and the aims of Public Archaeology. Papers from the Institute of Archaeology 15, 66-76.

Book

Demoule, J. P. 2007. L'archéologie préventive dans le monde. Apports de l'archéologie preventive a la connaisance du passé. Paris, La Décuverte.

Edited book

Durbin, G. (ed.) 1996. Developing Museum Exhibitions for Livelong Learning. London, GEM.

Section in book

McEwan, C., Silva, M. I. and Hudson, Ch. 2006. Using the past to forge the future: the genesis of the community site museum at Aguablanca, Ecuador. In H. Silverman (ed.), Archaeological site museums in Latin America. Gainesville, University of Florida Press, 187-216.

Internet reference

United Nations 1992, Agenda 21. Retrieved on 29 January 2010 from WWW [http://www.un.org/esa/dsd/agenda21/res_agenda21_00. shtml]

(As it is an online publication, all the quotes referring to an Internet address should be active links).

In the case of any other kind of reference not mentioned here, please contact the editor. 
Once the article has been received:

The process for the acceptance of papers will be easy and fast. Once the article has reached the editor, the decision will be taken in less than 48 hours. Papers rejected from the editor will not be considered again unless they undertake major changes. Correspondence will not be continued for those papers. If the paper is pre-accepted by the editor, it will be peer-reviewed by two different experts in the common blind process. After that, the author will be given feedback and advice in order to go over the article, which will be corrected again to check if it meets the requirements of the reviewers. Once this process has finished, the article will be edited as it will appear on the journal and returned to the author for a final check (only spelling mistakes or other details, not changes on the text). The commitment of the journal is to be able to complete the whole process in less than two months.

Work reports and reviews will not need to pass the peer-review process, but will be commented by the editor.

We will be publishing one volume per year (first trimester) and although we are willing to receive papers the whole year, full articles for next-year's volume should be sent before October in order to complete the process with time.

If you have any queries, please do not hesitate to contact the editor at: jasarqueologia@gmail.com 


\section{LIST OF DONORS}

We want to thank all the people that is helping to maintain this journal. Especially those that chose to use one of the procedures in the donations page. Every little help is welcome to continue with this project, and we expect to increase this list year by year with your help.

Thank you very much:

Vicky Papagiannopoulou

Giannis Papagiannopoulos

Alipio Sánchez

Ma Ángeles Sánchez

José Ma Almansa

Mayca Rojo

Gaëlle Cerruti

Carlos Tejerizo

Jacob Hilton

Patrice L. Jeppson

Gemma Cardona 


\section{AP: Ontine Journat in Public Archaeology}

\section{Editors:}

Jaime Almansa Sánchez \& Elena Papagiannopoulou

Email: almansasanchez@gmail.com

Assistant editors:

Dominic Walker

Amanda Erickson Harvey

Kaitlyn T. Goss

Reviews editor:

Alexandra Ion

Assistant production editor:

Alejandra Galmés Alba

Edited by:

JAS Arqueología S.L.U.

Website: www.jasarqueologia.es

Email: jasarqueologia@gmail.com

Address: Plaza de Mondariz, 6, 28029 - Madrid (Spain)

--

Cover Image: What are you looking at? (CAC)

Copyright (C) 2014 JAS Arqueología S.L.U. (edition) \& Authors (content)

ISSN: $2171-6315$

AP Journal is a peer-reviewed journal devoted exclusively to Public Archaeology. It is freely distributed online on the Website:

www.arqueologiapublica.es

You can also follow us on:

Blogger:

= http://arqueologiapublica.blogspot.com/

Twitter:

http://twitter.com/APjournal

Facebook:

http://www.facebook.com/APJournal 